\title{
TWO BRONZE AGE HOARDS WITH SHAFT-HOLE AXES FROM WEST GEORGIA
}

\author{
Materials for Communication Between Central and Eastern Europe ${ }^{1}$
}

\author{
JON I A PAKIDZE - S VEND H A N S E N
}

\begin{abstract}
The article deals with two hoards with axes from Georgia. The finds from Saqasria and Zeda Ilemi contained axes of the types Kozarac and Satchkhere, they can be dated to the first half of the $3^{\text {rd }}$ millennium BC. A new ${ }^{14} \mathrm{C}$-date from a tomb in the Lysogorskaja-6 necropolis in the Stavropol district of the North Caucasus also speaks for this dating. Thus, the beginning of the deposition of hoards in West Georgia is much earlier than previously assumed. Not only the axes, but also the form in which they were deposited is the result of communication between the Carpathians and the Caucasus.
\end{abstract}

Keywords: Georgia, Early Bronze Age, bronze hoards, shaft-hole axes, ovalplano-convex ingot, Saqasria, Zeda Ilemi, Sachkhere, Kozarac, Lysogorskaja, Mala Ternivka, Lebedi.

\section{PRELIMINARY REMARK}

In various essays and in his book, Štúdie ku komunikácii medzi strednou a východnou Európou v dobe bronzovej (2006), Jozef Bátora has examined the connections between the Carpathians and the Caucasus during the Copper, Bronze and Early Iron Ages on the basis of archaeological finds, thus making a significant contribution to including this dimension of East-West communication, which is important in terms of cultural history but has long been scarcely taken into account. In the following contribution, we will attempt to continue this thread.

\section{INTRODUCTION}

Hoards with bronze weapons, tools and jewellery are one of the most striking cultural phenomena of the Bronze Age of the $2^{\text {nd }}$ millennium BC in many parts of Europe. Until today, they have been the subject of intensive and partly controversial research. Hoards are the end point of a social practice whose logic only gradually becomes understandable in the perspective of the longue durée (Hansen 2019; Jeunesse 2017). Even after more than 150 years of scholarly study of the finds (Worsaae 1866), the search for motives for depositing bronze objects has not yet come to an end. They are also considered from the point of view of economic and trade history as well as from the point of view of the history of craftsmanship or religion. All of this is to some extent justified, since the hoards contain products of craftsmanship. Some of them represent considerable values and contain objects from many different regions. After all, they were deposited as votive offerings for the imaginary powers, spirits and gods (Hansen 2013; 2019).

The limits of the phenomenon of depositing metal objects have not yet been sufficiently understood. The newly discovered cult site Shaitanskoye Ozero II in the Transural region is therefore of great importance. On a lake shore in the early $2^{\text {nd }}$ millennium BC, a number of metal objects were deposited: numerous metal objects, especially daggers, lance tips and axes (Korochkova et al. 2010). Some of them were deposited completely and intact, others were intentionally broken and fragmented. They show a surprisingly wide spectrum of practices known from Central European deposition sites. If the Seima-Turbino phenomenon is understood as a specific depositing practice, then this custom extends far beyond the Urals to the east.

According to the present knowledge, the Kolchic hoards represent another eastern limit of the hoarding phenomenon (Reinhold 2005). However, the state of publication is extremely modest. From Georgia alone, at least 214 hoards with about 4000 objects are known.

\section{THE HOARDS OF THE COLCHIS CULTURE}

A large number of hoards is connected with the Colchis Culture, spanning from 1600 to 700 BC in

\footnotetext{
1 The article was written within the framework of the DFG-funded research project 'The Bronze and Early Iron Age hoards of the Colchis Culture in Western and Central Caucasia'. A shorter German-language version of this article will be published in the journal Das Altertum.
} 


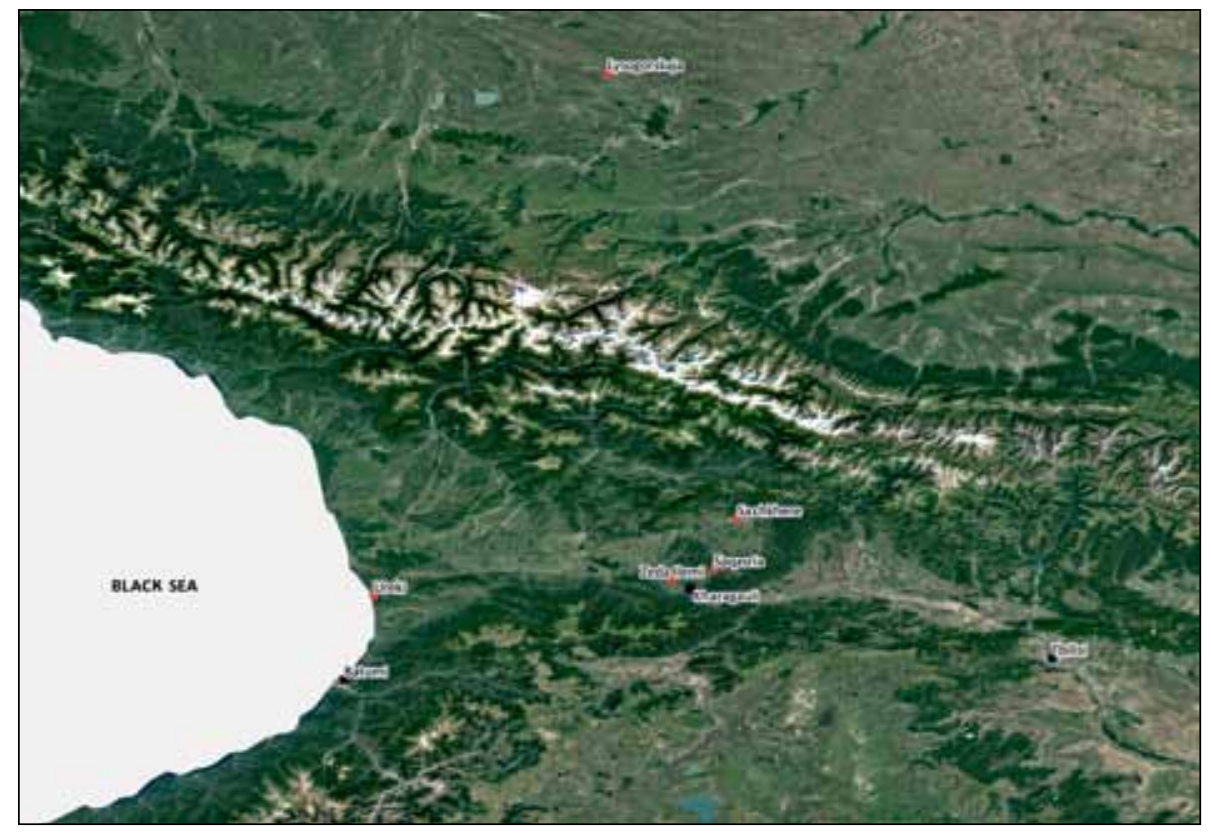

Fig. 1. Schematic map with the most important sites mentioned in the text (map by M. Karaucak).

West Georgia (Apakidze 2000, 185; 2009, 12; Japaridze 1991, 202; Lordkipanidze 1991, 95-109). Between 1200 and $700 \mathrm{BC}$, this culture was not only widespread in western Georgia, but also in eastern Georgia in the region of Meskhetia and partly in Shida Kartli. The large part of the Aragvi Gorge in East Georgia as well as Northeast Turkey up to the present-day Turkish cities of Ordu and Samsun also belong to the distribution area of this culture (Apakidze 2009, fig. 1). The central and western regions of North Caucasia, where today the republics of the Russian Federation Chechnya, Ingushetia, North Ossetia, Kabardino-Balkaria and Karachay-Cherkessia are located, were territories of the Koban Culture. These cultural phenomena in the Southern and Northern Caucasus are addressed by some researchers as a unity of others, and in turn as two separate cultures.

In 1965, D. Koridze published a first catalogue and analyses of the bronze hoards of the Colchis Culture (Koridze 1965, 10-49). As the oldest hoard, the Ureki find is dated to the period of the $18^{\text {th }}$ to the $16^{\text {th }}$ century BC. It also marks the last quarter of the West Georgian Middle Bronze Age. A younger hoard stage is dated between the $16^{\text {th }}$ and the beginning of the $14^{\text {th }}$ and the beginning of the $13^{\text {th }}$ century $\mathrm{BC}$, further hoard stages are dated to the $13^{\text {th }}-12^{\text {th }}$ century $B C, 12^{\text {th }}-11^{\text {th }}$ century $B C, 11^{\text {th }}-10^{\text {th }}$ century $B C, 10^{\text {th }}-8^{\text {th }}$ century $B C$ and $8^{\text {th }}-7^{\text {th }}$ century BC. The chronology of A. Ramishvili $(1974,88)$ should also be mentioned. He dated the hoard of Ureki to the $16^{\text {th }}-15^{\text {th }}$ century BC, which seems very unlikely. There is a clear need for a more precise chronology.
In Georgian and Russian research, the hoards of the Colchis Culture are considered to be 'founders' or 'merchant depots'. They were destined for further use and the economic background was decisive for their deposition. According to A. A. Iessen, they were 'foundry hoards' (Iessen 1935, 117). This was followed by B. A. Kuftin (Kuftin 1949, 222; 1950, 162). G. Gobejishvili and $\mathrm{O}$. Japaridze divided the hoard finds into two types: most of them belonged to 'foundry hoards' and relatively few to 'merchant hoards' (Gobejishvili/ Japaridze 1959, 146, 147). According to O. Gambaschidze (1963), most hoards were owned by large patriarchal families, perhaps consisting of 30-60 persons. However, he also considered the possibility that many of these hoards were to be 'foundry hoards'. Ju. N. Voronov connected the hoards with 'workshops' (Voronov 1969, 73). He even called these finds 'klady-masterskie', hoard workshops. O. Lordkipanize, on the other hand, understood the Colchis hoards as a multifunctional phenomenon, which had religious, socio-economic and ethno-cultural dimensions (Lordkipanidze 2001, 189). In his opinion, most depots of Colchis had a ritual meaning and were gifts to the gods.

\section{BEGINNING OF THE HOARDING PHENOMENON IN COLCHIS IN THE $3^{\text {RD }}$ MILLENNIUM BC}

Up to now, it seemed that hoarding had taken place in the $2^{\text {nd }}$ millennium $B C$ in the South Caucasus and therefore apparently represented a late innovation. In fact, two find complexes show that the hoard 


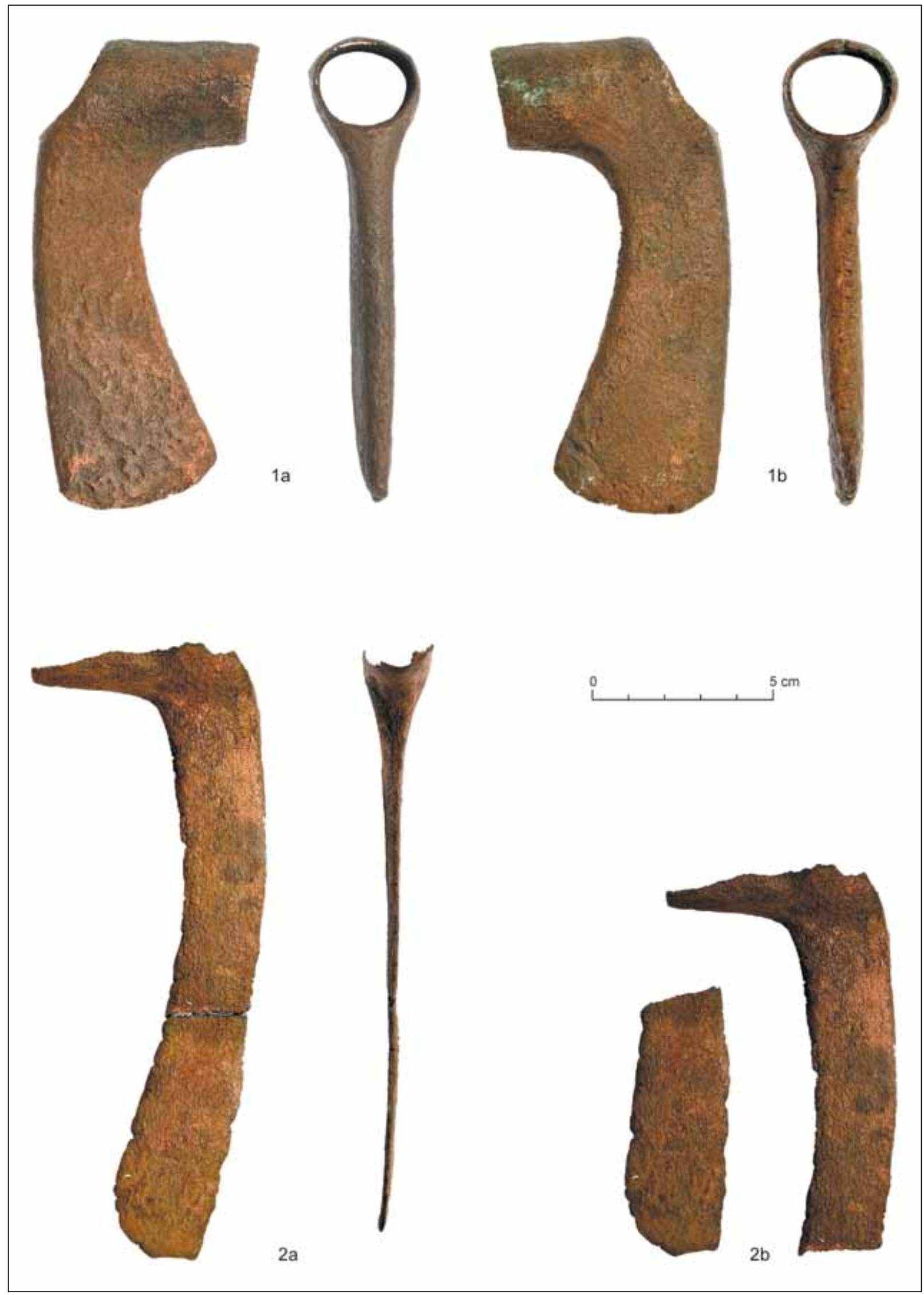

Fig. 2. Hoard of Saqasria (photo by N. Kopaliani). 


$$
\begin{aligned}
& 8979 \\
& 899
\end{aligned}
$$


custom had already been in practice in the earlier Colchis periods. The two hoards are located in the historical museum in the small town of Kharagauli.

\section{THE HOARD OF SAQASRIA}

According to the documents of the Historical Museum Kharagauli, the hoard of Saqasria was discovered in 1984 during the construction of the house. No further finds were found. In 1985, the find was purchased for 350 rubles.

1. Bronze shaft-hole axe (KHHM, 6117). The shaft-hole is round-oval on both sides. The cutting edge is hardly rounded and blunt. The axe is restored and preserved. Length $12.9 \mathrm{~cm}$, cutting width $4.5 \mathrm{~cm}$, weight $379 \mathrm{~g}$ (Fig. 2: 1).

2. Bronze axe (KHHM, 6117 $)$ ). The body is thin and broken in two parts. The neck and almost the entire shaft-hole are missing. The tip of the blade is also broken off. Length of the upper part $10.4 \mathrm{~cm}$, maximum width of the body $2.6 \mathrm{~cm}$, thickness at the break $0.3 \mathrm{~cm}$, weight $113 \mathrm{~g}$; length of the lower part $7.1 \mathrm{~cm}$, thickness at the cutting tip $0.1 \mathrm{~cm}$, weight
$35 \mathrm{~g}$, maximum width of the body $3.0 \mathrm{~cm}$; total length $17,5 \mathrm{~cm}$, total weight $148 \mathrm{~g}$ (Fig. 2: 2).

\section{THE HOARD OF ZEDA ILEMI}

According to the inventory book of the Kharagauli Museum, the hoard of Zeda Ilemi was discovered in 1979 in the former vineyard of the village on the slope of the hill Khvadieti during agricultural works. The bronze objects of the hoard were located within a radius of one or two metres (Kvirkvaial Jibladze 2019, 50). The hoard consists of two bronze axes and one ingot. It was purchased for 10 roubles.

1. Bronze shaft-hole axe (KHHM, 520). A bronze piece is clamped in the shaft-hole. The axe is restored and preserved. Length $15.8 \mathrm{~cm}$, cutting width $5.1 \mathrm{~cm}$, weight $598 \mathrm{~g}$ (Fig. 3: 1).

2. Bronze shaft-hole axe (KHHM, 521). Length $16.2 \mathrm{~cm}$, cutting tip $4.0 \mathrm{~cm}$, weight $514 \mathrm{~g}$ (Fig. 3: 2).

3. Plano-convex ingot with elliptical shape (CHHM, 522). Length $12.3 \mathrm{~cm}$, width in the middle $5.7 \mathrm{~cm}$, maximum thickness $2.0 \mathrm{~cm}$, weight $472 \mathrm{~g}$ (Fig. 4).

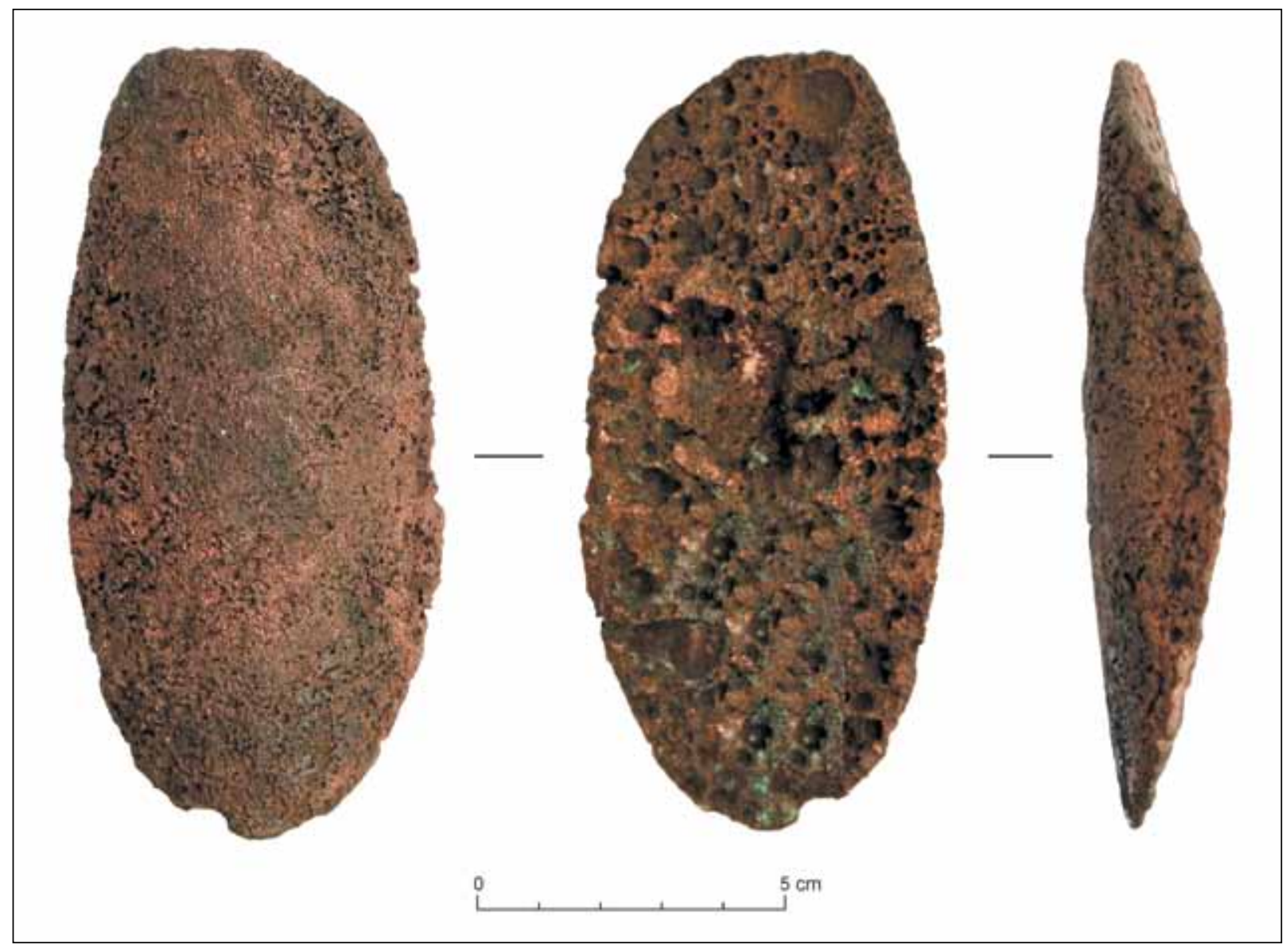

Fig. 4. Hoard of Zeda Ilemi (photo by N. Kopaliani). 


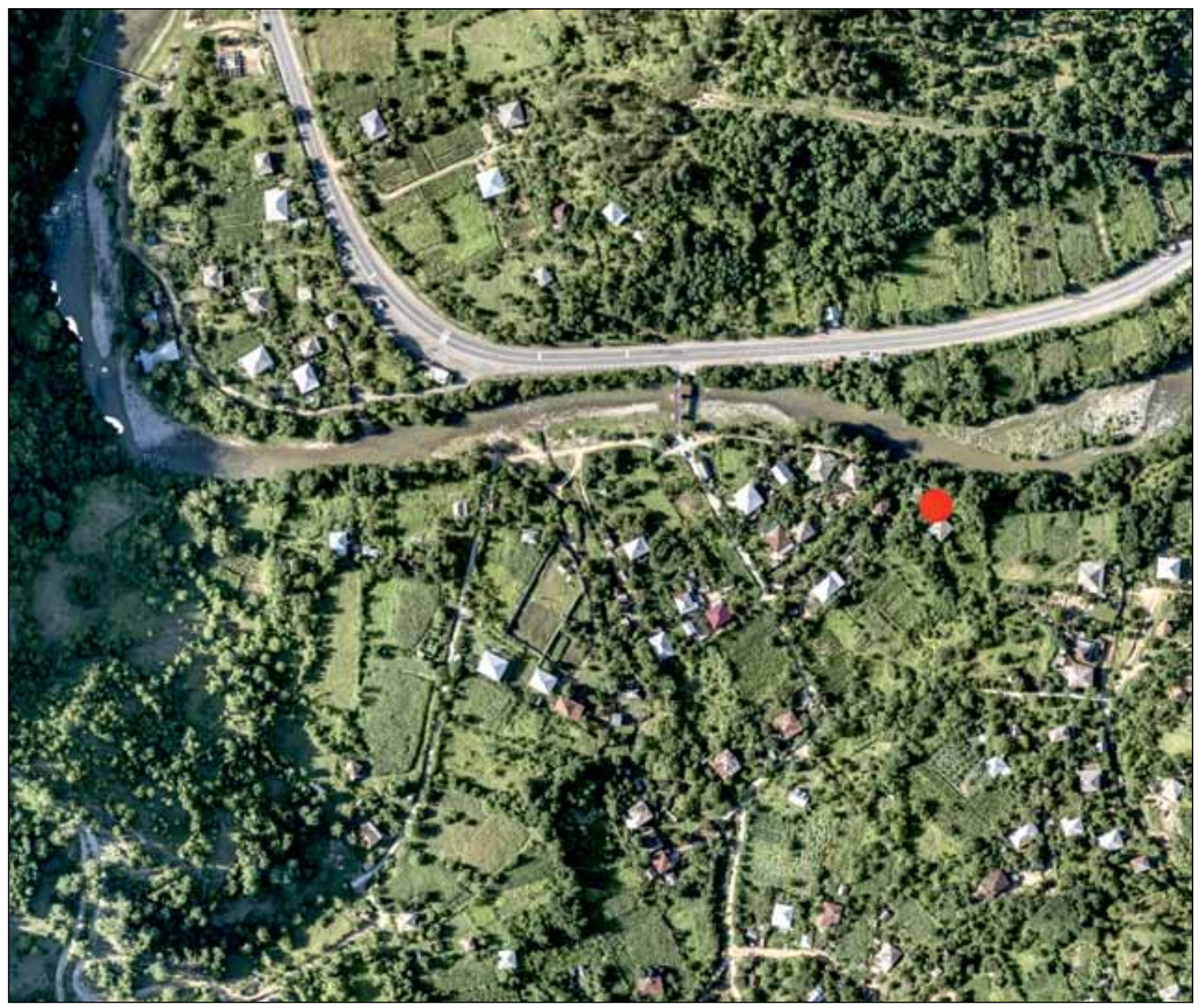

Fig. 5. Find situation of the Zeda Ilemi hoard (photo by J. Krumnow).

The finds were first published in 2010 (Gambaschidze et al. 2010, 380, 381, pl. 27: 458-460; a bronze shaft hole axe from the hoard of Saqasria: Fig. 2: 1 and a bronze shaft hole axe from the hoard of Zeda Ilemi: Fig. 3: 2 are missing). The find from Zeda Ilemi has also been discussed by L. Jibladze and R. Kvirkvaia (Jibladze 2016, 54; Kvirkvaia/Jibladze 2019, 55). Chemical analysis of the axes from Zeda Ilemi revealed that they are functional arsenic bronzes.

The sites were identified in the field in summer 2019 by L. Tchabashvili and J. Krumnow. The aerial photographs show that both hoards have a very similar deposition situation not far from a river or traffic route. The site of the Saqasria hoard is located about $15 \mathrm{~m}$ to $17 \mathrm{~m}$ from the left bank of the river Dzirula (Fig. 5). The hoard of Zeda Ilemi was found about $200 \mathrm{~m}$ from the left bank of the river Dzirula (Fig. 6).

\section{THE AXES}

The broken axe from the Saqasria find belongs to a type common in the South Caucasus, characterized by the thin long socket and a curved blade widening towards the cutting edge. According to I. Gambaschidze et al.'s $(2010,155,156)$ terminology, the Saqasria axe belongs to group II of axes with a long socket. It is closely related to group III. A number of axes are damaged and show signs of use, it therefore does not seem to be a pure parade object.

Comparable axes (Fig. 7) are known in West Georgia, especially from the tombs of Sachkhere (Japaridze 1961, 123, 129, fig. 23: 1; Pkhakadze 1993, pl. XVI: 1 ; XVII: 1 ; XVIII). They are found there with slender flat axes, grip daggers as well as daggers with ornamented full handles, lance tips, stone arrowheads as well as needles with large T-shaped 


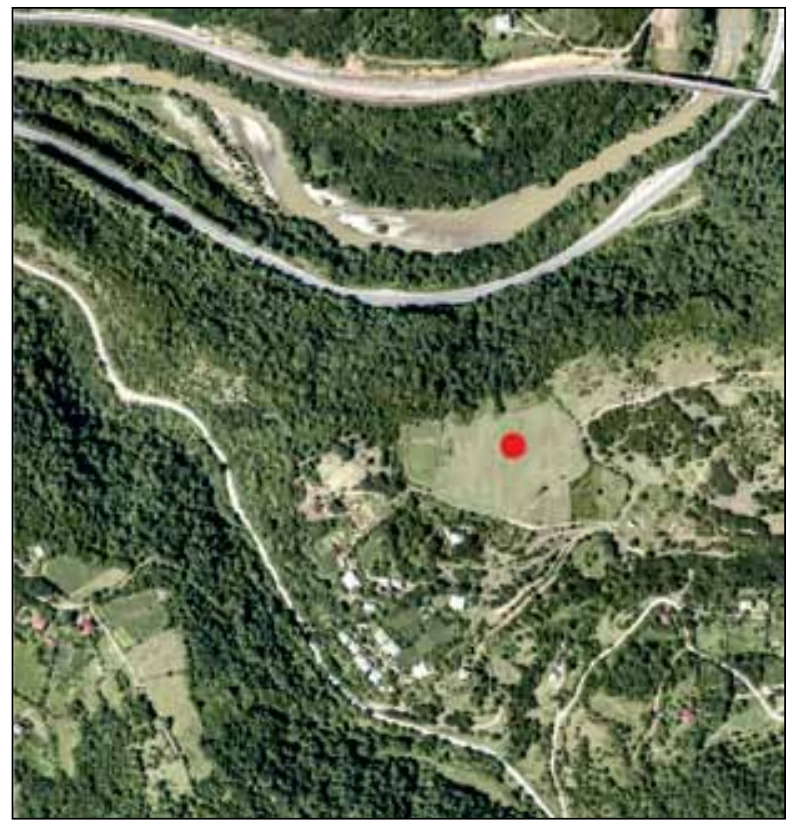

Fig. 6. Situation of the Saqasria hoard (photo by J. Krumnow). or volute-shaped heads and clay vessels of the Late Kura-Araxes Culture. The tombs of Sachkhere, which are located in four different localities (Japaridze 1961, 122-140), have been excavated by various researchers since the beginning of the $20^{\text {th }}$ century, but a comprehensive publication of these excavations is still missing. Of the 35 documented axes from Sachkhere, only a few have been chemically examined. However, they seem to regularly consist of copper-arsenic alloys (Abesadze 1969; 2011; Japaridze 1961, 197-201, table 2). The finds of Sachkhere represent a time horizon that can be dated before the appearance of the Kurgan cultures Martqopi and Bedeni, i. e. before about 2500 BC. There are no ${ }^{14} \mathrm{C}$-datings from Georgia, so that only a general dating into the first half of the $3^{\text {rd }}$ millennium BC is possible (Tchabashvili/Bastert-Lamprichs/Giemsch 2018, 308, fig. 6: 1-3; 7: 1-3).

The finding of a comparable axe (Fig. 8) from the Lysogorskaja-6 necropolis between Pyatigorsk and Georgijevsk in the Stavropol district is therefore all the more important (Korenejskij/Berezin/Gabuev 2018, fig. 6: 4). Kurgan 3 measured 7.2 metres in height and 50 or 64 metres in diameter. It was the

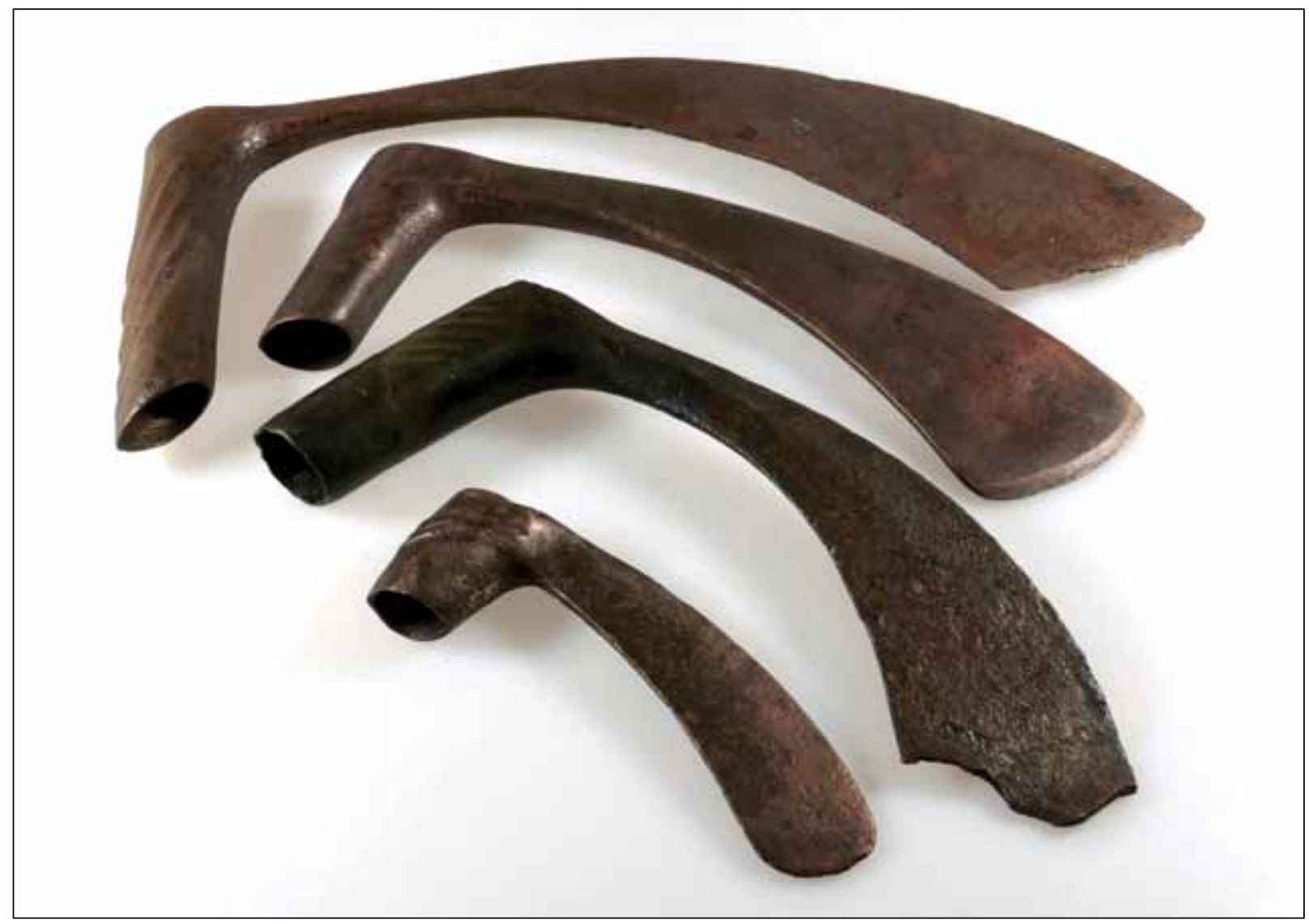

Fig. 7. Shaft-hole axes from Satschkhere. The uppermost axe is $22.2 \mathrm{~cm}$ long (Georgian National Museum Tbilisi; photo by S. Hansen). 


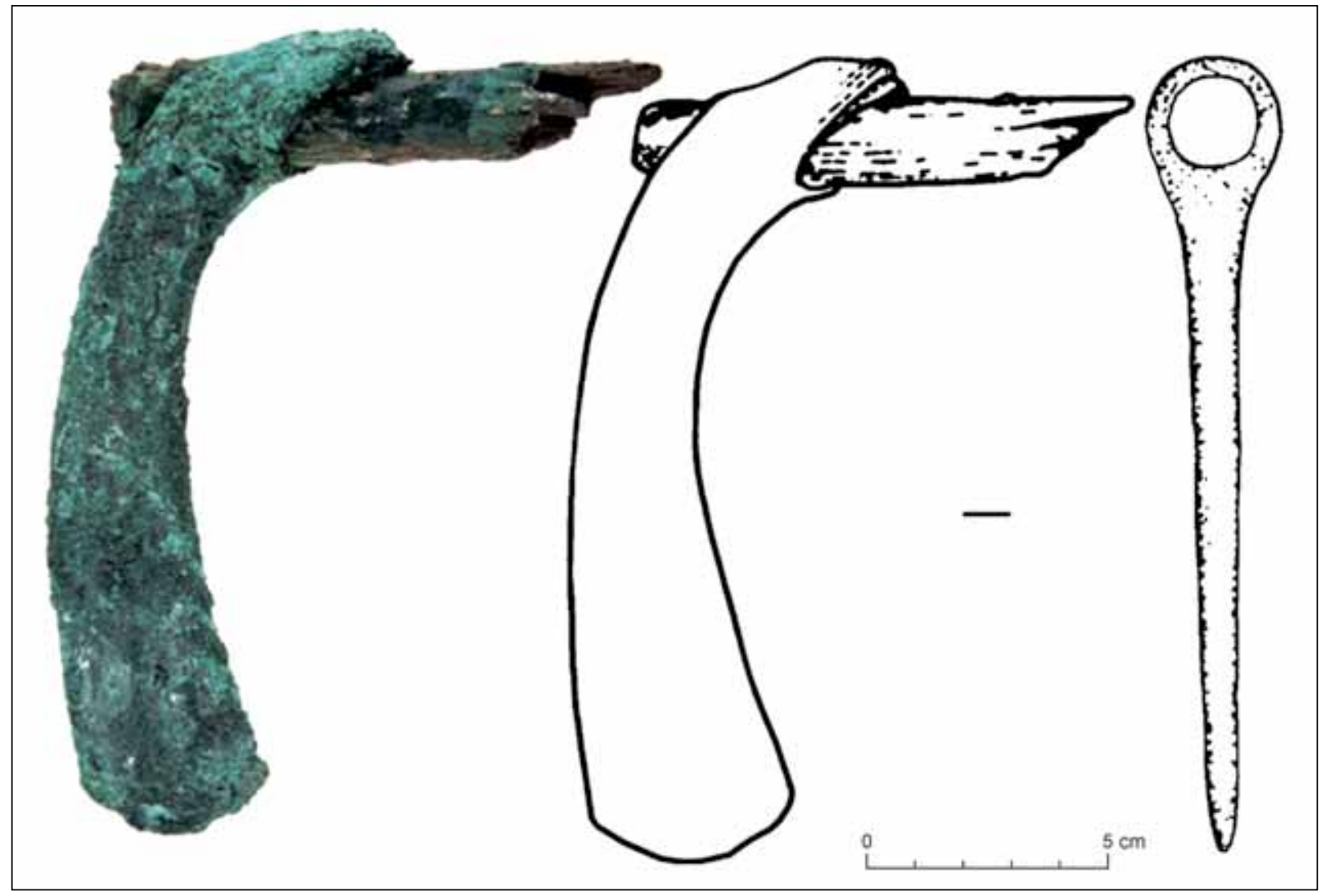

Fig. 8. Shaft-hole axe from tomb 3 of Kurgan 4 in the Lysogorskaja-6 necropolis (after Korenejskij/Berezin/Gabuev 2018).

largest hill in the vicinity. Burial 4 is the only Bronze Age grave, graves 1-3 are Iron Age. Two cattle skulls were found next to the grave pit, which can be interpreted as a symbol for an oxen team. The interred individual lay on his back in the wooden chamber and the bronze grave goods were placed on wooden supports. They included the axe, a flat axe, two daggers, a small (now restored) bronze vessel with spiral decoration. The outstanding find is a $38 \mathrm{~cm}$-long, all-metal goad, which is a unique piece. Among the metal findings is also a small gold ring. The deceased individual in grave 4 was undoubtedly a socially exceptionally exposed person, buried with exquisite grave goods. The gold ring can easily be understood as a status indicator. The bronze vessel shows not only the access of its owner to technically innovative products, but also the need for an extraordinary vessel from which special, perhaps intoxicating drinks were consumed. The cattle team and the driving spine show the gentleman as the owner of a carriage. However, the bronze goad is a weapon that could also be used to drive people. The axe is probably an imported product from the south and underlines the man's long-range connections. The dating of the tomb, in contrast to what is presented by S. N. Korenevskij and others, can not only refer to typological estimates, but also to a concrete ${ }^{14} \mathrm{C}$-date from this tomb, which we have already published in the context of our DNA study (Wang et al. 2019; supplementary information). This falls in the time between 2863-2581 calBC (4122 \pm 23 BP, MAMS-29825) and confirms the dating

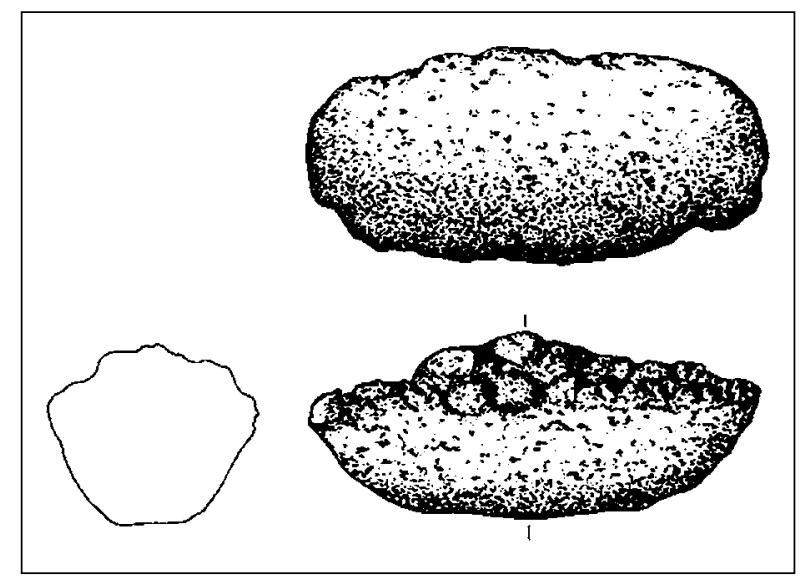

Fig. 9. Ingot from Maadi (after Rikzana/Seeher 1989). 


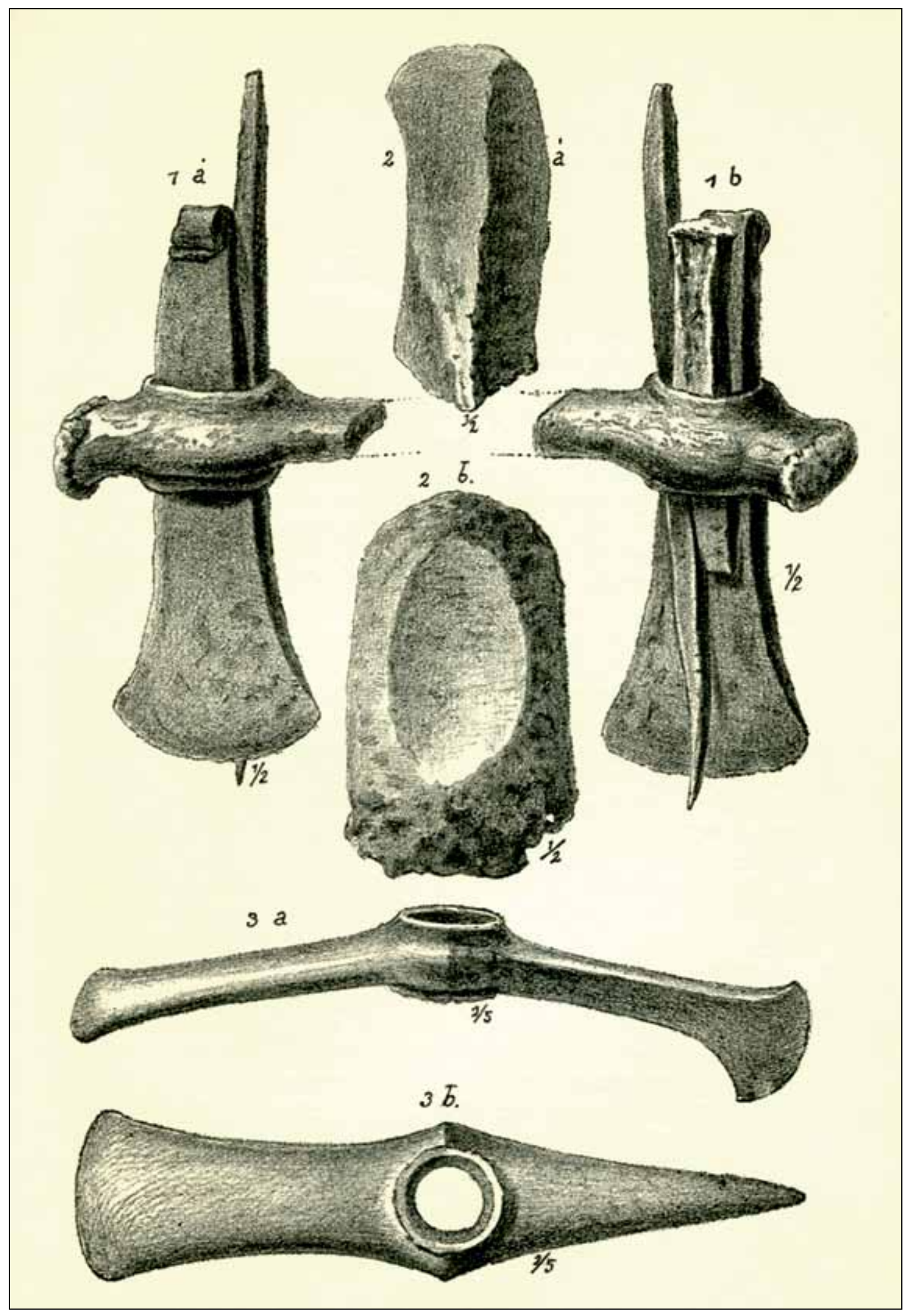

Fig. 10. Ingot from Szeged 'Sziller' (after Pulszky 1884). 
of the axes of the Sachkhere-type before the time of the kurgans of Martqopi and Bedeni.

The two axes from Ilemi and the second axe from Saqasria are characterized by a more compact form. The blade is significantly shorter and wider. The shaft-hole socket is set off from the blade by a weak heel. They belong to group I in the scheme of I. Gambaschidze et al. (2010, 154).

While axes with a curved edge are a typical South Caucasian form, axes with a set-back blade represent a form that is very widespread and known as the Kozarac type (Truhelka 1909) after a Bosnian hoard. They also belong to the first half of the $3^{\text {rd }}$ millennium BC (Kleitsas 2019). The chronological approaches for the axes are to be understood as rough guidelines. There is a lack of sufficient ${ }^{14} \mathrm{C}$ -data from dated complexes to better narrow down the durations of these axes. However, the differences to the Stublo type (Klochko/Klochko 2013), which can be considered a late variant of the Kozarac axes, lie both in the contour of the blade back and the shape of the shaft-hole.

In Georgia, comparable axes can still be found in the early Kurgan culture in Martkopi, Kurgan IV (Japaridze 1991, 141, fig. 44: 1; pl. XXI: 1; 1998, 24, fig. 12; table 14; Kvirkvaia/Jibladze 2019, 53). It is an open question whether this is actually to be classified later than Sachkhere (Kavtaradze 1981, 95; Orjonikidze 2015, $6,7)$ or whether there is an overlap in time.

\section{THE INGOT}

The oval plano-convex ingot (Fig. 4) from the Ilemi hoard is a hitherto unique piece in the South Caucasus. According to the chemical analysis published by R. Kvirkvaia and L. Jibladze (2019, 54,55 , table 1), it is allegedly composed of copper $(98.180 \% \mathrm{Cu})$ with smaller portions of silver $(0.455 \% \mathrm{Ag})$, but also portions of an unknown element $(416 \% \mathrm{Ci})$. There is undoubtedly still a need for correction.

The ingot was probably cast in a clay mould. Clay moulds for hatchets, but also ingots of various shapes have been handed down since the early $4^{\text {th }}$ millennium BC, for example from Tepe Ghabristan and Arisman in Iran (Helwing 2010), in Georgia from Dzedzwebi (Stöllner/Gambashidze 2018) and from the Areni cave in Armenia (Bobokhyan et al. 2014), to name a few sites. Moulds and crucibles of clay have been known since the early $4^{\text {th }}$ millennium BC in a geographical area between Iran and Switzerland. Clay moulds for flat rectangular and oval ingots are known from Hujayrāt al-Ghuzlān near Aqaba in Jordan (Pfeiffer 2009) and from Maadi in Lower Egypt (Rikzana/Seeher 1989), where they were found in the first half of the $4^{\text {th }}$ millennium BC. Oval metal ingots (Fig. 9) have also been handed down from both sites.

Still older is possibly the oval copper ingot (Fig. 10) from the hoard of Szeged-Sziller, Com.

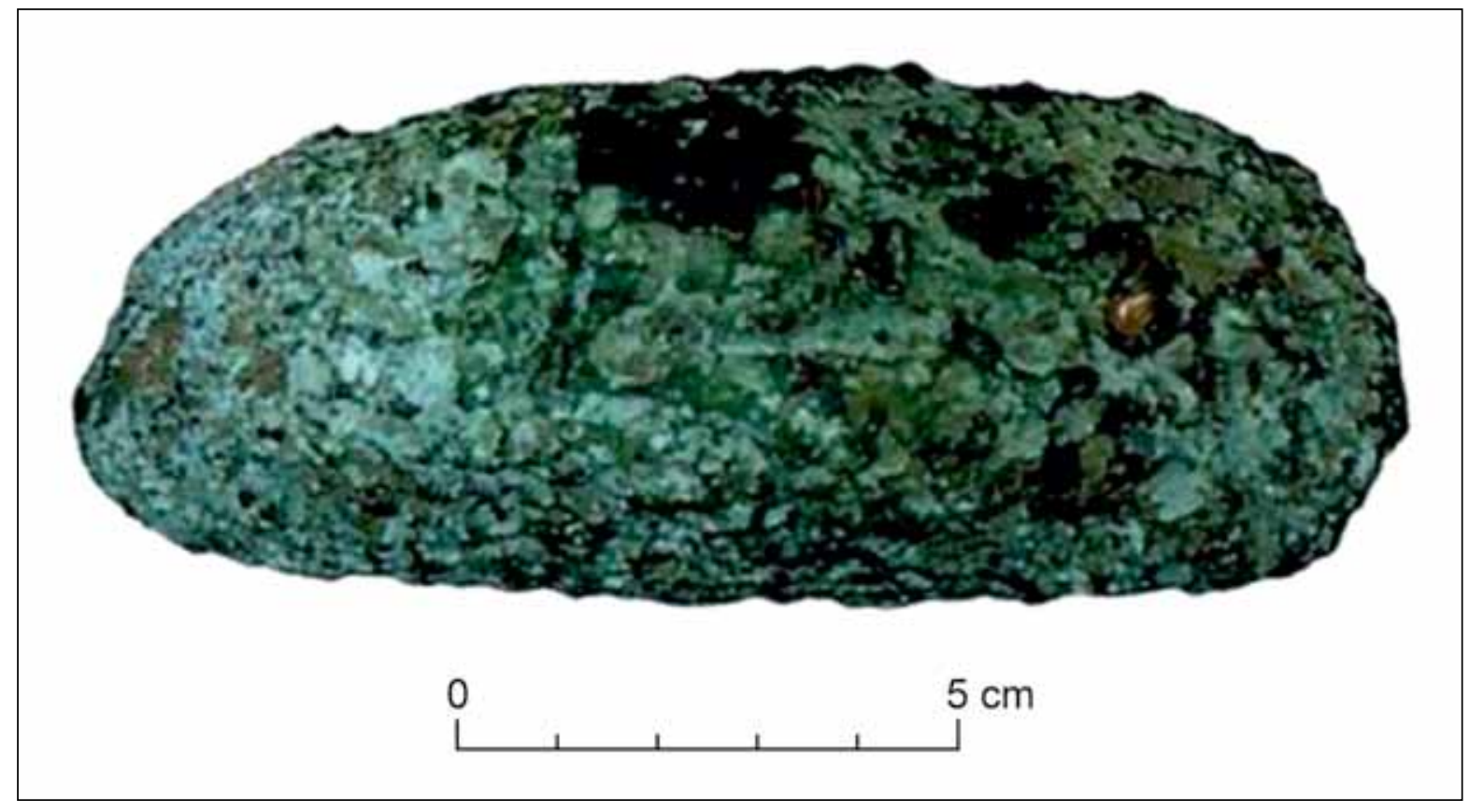

Fig. 11. Ingot from Velika Laole (after Šljivar/Kuzmanović-Cvetković/Živković 2011). 

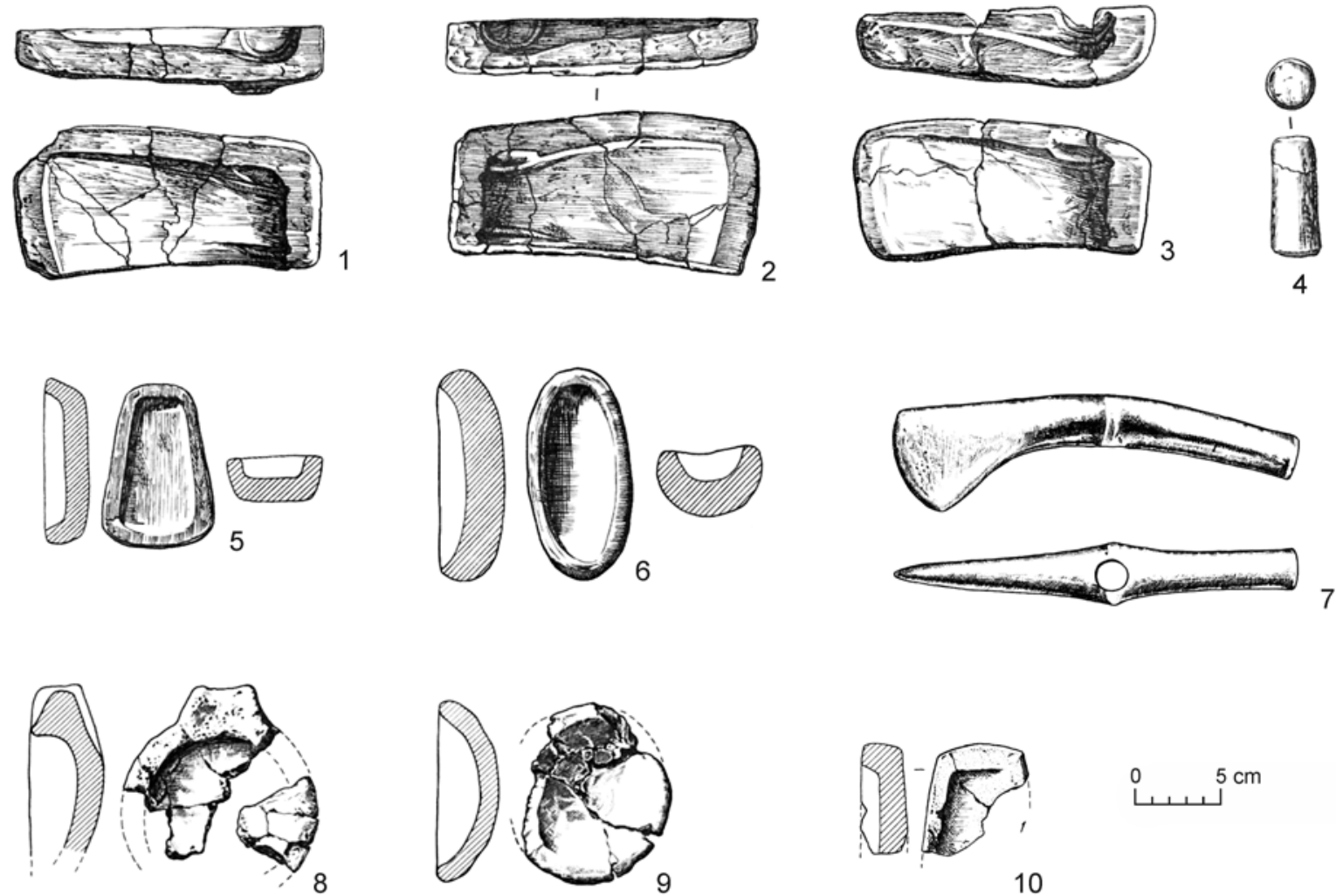

10
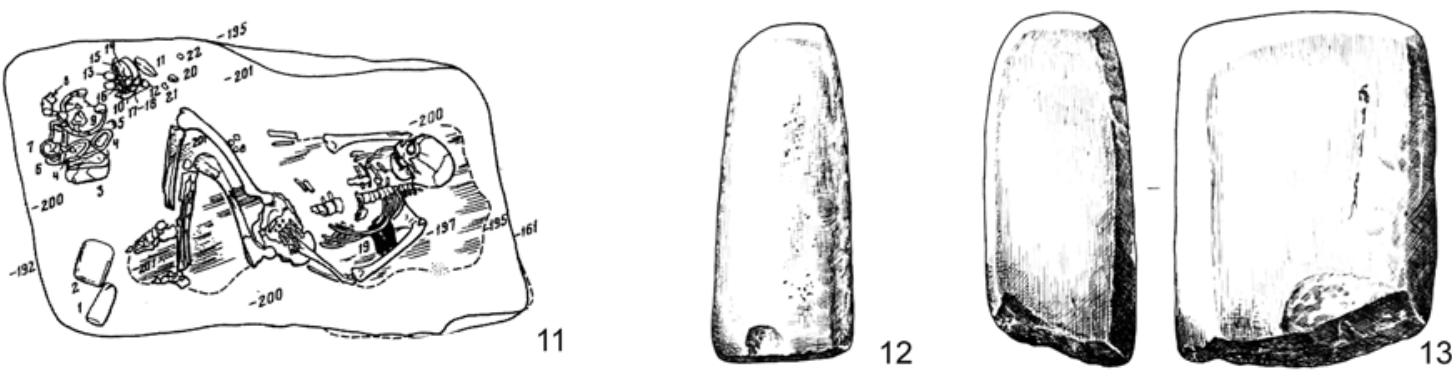

Fig. 12. Moulds from the tomb of Lebedi (after Gej 1986; modified).

Csongrád (Patay 1943, pl. 50: 1, 2, 9-12; Pulszky 1884, 22-24, fig. 1; 2; Sava 2015, 277, 278). Apart from the ingot, it contained a broken axe with three chisels of different shapes wedged into the shaft-hole and a cross-edged axe of the Jászladány type. It can be connected with the Bodrogkeresztúr Culture, with recent ${ }^{14} \mathrm{C}$-data already existing for the last quarter of the $5^{\text {th }}$ millennium. For the Jaszladány axes, however, a continued use into the early $4^{\text {th }}$ millennium $\mathrm{BC}$ is probable.

Another oval, $13.5 \mathrm{~cm}$-long and $5.6 \mathrm{~cm}$-wide ingot (Fig. 11) comes from Velika Laole, Gde. Petrovac na Mlavi in eastern Serbia, but is unfortunately undated (Šljivar/Kuzmanović-Cvetković/Živković 2011, pl. 40: 3). Occasionally, oval ingots still exist until the Late Bronze Age like the silver ingots from Pyla Kokkinokremos in Cyprus (Kassianidou/Knapp 2005, fig. 9: 4).

Open clay forms are numerously documented in the third millennium. They are found south of the Caucasus in settlements such as Kvatskhela or Natsargora (Gambaschidze et al. 2010, No. 98, 478, pl. VI: 98; XXVIII: 478). In the North Pontic region, crucibles, casting moulds for axes and ingots are sometimes preserved as burial objects in the graves of metalworkers (Bátora 2003). A remarkable find comes from Mala Ternivka, Zaporizhia oblast' in the Ukraine, where a set of six crucibles and nine 
moulds was found in a burial of the catacomb burial culture (Kubyshev/Chernyakov 1985). Such moulds are sometimes also classified as crucibles, as in the case of a similar object (Fig. 12) from tomb 10 in Kurgan 3 of Lebedi (Chernykh 1992; Gej 1986). But the difference is only gradual and, in practice, an open clay mould for an axe could be placed in the fire like a crucible. The grave of Lebedi is placed at the beginning of the $3^{\text {rd }}$ millennium $B C$ and is thus somewhat older than the ingot of Ilemi.

The number of oval ingots mentioned here is too small to draw far-reaching conclusions. They did not belong to the canon of objects that found their way into the hoard. Therefore, the Ilemi ingots and the other specimens mentioned here are rare and therefore important evidence of the history of craftsmanship, which should be given more attention in the future.

\section{CONCLUSIONS}

The revision of the chronology on the basis of ${ }^{14} \mathrm{C}$ -data meant considerable changes for the $4^{\text {th }}$ and $3^{\text {rd }}$ millennium $\mathrm{BC}$. The resulting consequences for the classification of certain archaeological find groups and the historical interpretations behind them are, of course, only slowly becoming apparent. This is especially true for the history of depositions, the longue durée of which can be demonstrated by means of an object as exposed as the copper or bronze axe.

With the two hoards from Saqasria and Zeda Ilemi, the custom of depositing hoards in West Georgia can now be traced back to the first half of the $3^{\text {rd }}$ millennium BC. Other possible hoards are from Zahesi, Zemo Avchala (lance tip and shaft-hole axe), Mejvrikhevi, Gori district (two shaft-hole axes), Gufta village, Mashiv Uiati place, Tskhinvali district (Gambaschidze et al. 2010, pl. 15: 236, 237; 16: 242, 243; 17: 257, 258). Of course, the numerous individual finds of such axes, which originate from destroyed graves as well as individual depositions, must also be included in the analysis. Only recently, axes from the Enguri River in Svanetia have been published, among them an axe of the Sachkhere type (Kvitsiani/ Jibladze 2015, 120, pl. 3: 3). These water body finds can also be understood as offerings.

Since the $4^{\text {th }}$ millennium BC, the Caucasus was integrated into the large-scale network of Bronze Age communication. In this exchange, metal played an important role, both as raw material and as a finished product and as an input for the imaginary powers in hoards or as burial objects. Not only objects circulated between East and West, but also social practices, as shown by the example of the hoards.

\section{LITERATURE}

Abesadze 1969 - Ts. Abesadze: Litonis tsarmoeba amierkavkasiashi $d z v$. ts. III atastsleulschi (On metal production in Transcaucasia in the $3^{\text {rd }}$ millennium BC). Tbilisi 1969.

Abesadze 2011 - Ts. Abesadze: Brinjaos metalurgiis istoriidan sakartveloshi (On the history of bronze metallurgy in Georgia). Tbilisi 2011.

Apakidze 2000 - J. Apakidze: Ein umfangreicher Bronzehort aus der Werkstattsiedlung der Kolchis-Kultur in Očchomuri in Westgeorgien. Prähistorische Zeitschrift 75, 2000, 184-212.

Apakidze 2009 - J. Apakidze: Die Spätbronze- und Früheisenzeit in West-und Zentralkaukasien. Chronologische Studien zur Kolchis-Kultur 1600-700 v. Chr. PAS 24. Rahden/ Westf. 2009.

Bátora 2003 - J. Bátora: Kupferne Schaftlochäxte in Mittel-, Ost und Südosteuropa (Zu Kulturkontakten und Datierung - Äneolithikum/Frühbronzezeit). Slovenská archeológia 51, 2003, 1-38.

Bátora 2006 - J. Bátora: Štúdie ku komunikácii medzi strednou a východnou Európou v dobe bronzovej. Bratislava 2006.

Bobokhyan et al. 2014 - A. Bobokhyan/K. Meliksetian/ B. Gasparyan/P. Avetisyan/C. Chataigner/E. Pernicka: Transition to Extractive Metallurgy and Social Transformation in Armenia at the End of the Stone Age. In: B. Gasparyan/M. Arimura (eds.): Stone Age of Armenia. Kanazawa 2014, 283-314.
Chernykh 1992 - E. N. Chernykh: Ancient Metallurgy in the USSR. The Early Metal Age. Cambridge 1992.

Gambaschidze 1963 - O. Gambaschidze: Tkhmoris Gandzi (The hoard from Tkhmori). Tbilisi 1963.

Gambaschidze et al. 2010 - I. Gambaschidze/G. Mindiaschwili/G. Gogotschuri/K. Kachiani/ I. Dschaparidze: Udzvelesi metalurgia da samto saqme saqartveloshi dzv. ts. VI - III atastsleulebshi (Alte Metallurgie und Bergbau in Georgien in 6. - 3. Jt. v. Chr.). Tbilisi 2010.

Gej 1986 - A. N. Gej: Pogrebenie liteyshchika novotitorovskoy kultury iz Nizhnego Prikuban'ya. In: G. E. Afanas'ev (red.): Arkheologicheskie otkrytiya na novostroykakh. Moskva 1986, 13-32.

Gobejishvili/Japaridze 1959 - G. Gobejishvili/O. Japaridze: Gvianbrinjaos khanis dzeglebi dasavlet sakartveloshi (Late Bronze Age monuments in West Georgia. Sakartvelos arkeologia. Archaeology of Georgia). Tbilisi 1959, 129-155.

Hansen 2013 -S. Hansen: Deponierungen in der Bronzezeit Europas. In: Yu. Piotrovsky (red.): Bronzovyj vek. Evropa bez granic. Chetvertoe - pervoe tysyacheletiya do novoj ery = Bronzezeit. Europa ohne Grenzen. 4.-1. Jahrtausend v. Chr. Sankt-Peterburg 2013, 279-289.

Hansen 2019 - S. Hansen: Metalldeponierungen in Europa. Ein Phänomen der Langen Dauer, der Konjunkturen und der Ereignisse. In: S. Hye/U. Töchterle (Hrsg.): 
UPIKU:TAUKE. Festschrift für Gerhard Tomedi zum 65. Geburtstag. UPA 339. Bonn 2019, 201-218.

Helwing 2010 - B. Helwing: The small finds from Arisman. In: A. Vatandoust/H. Parzinger/B. Helwing (eds.): Early Mining and Metallurgy on the Western Central Iranian Plateau. The first five years of work. Mainz 2010, 254-327.

Iessen 1935 - A. A. Iessen: K voprosu o drevneyshey metallurgii medi na Kavkaze. Izvestiya Gosudarstvennoy akademii istorii material'noy kul'tury 120. Moskva - Leningrad 1935, 9-237.

Japaridze 1961 - O. M. Japaridze: Qartveli tomebis istoriisatvis litonis tsarmoebis adreul saphekhurze (On the History of Georgian Tribes in the Aeneolithic and Early Bronze Ages). Tbilisi 1961.

Japaridze 1991 - O. Japaridze: Saqartvelos arqeologia, qvisa da brinjaos khana (Archäologie Georgiens. Stein- und Bronzezeit). Tbilisi 1991.

Japaridze 1998 - O. Japaridze: Kartveli tomebis etnokulturuli istoriisatvis dzv. ts. III atastsleulshi. Adrekhorganuli kultura (On the ethnocultural history of the Georgian tribes in the $3^{\text {rd }}$ millennium BC. Early Kurgan culture). Tbilisi 1998.

Jeunesse 2017 - Chr. Jeunesse: From Neolithic kings to the Stafford-shire hoard. Hoards and aristocratic graves in the European Neolithic: the birth of a 'Barbarian' Europe? In: P. Bickle/V. Cummungs/D. Hofmann/ J. Pollard (eds.): The Neolithic of Europe. Papers in Honour of Alasdair Whittle. Oxford 2017, 175-187.

Jibladze 2016 - L. Jibladze: Kolchuri kulturis gvianbrinjao-adrerkinis khanis gandzebtan dakavshirebuli zogierti sakitkhisatvis (On some issues of Late Bronze-Early Iron Era Treasures of Colchis Culture). Amirani. Journal of the International Caucasological Research Institute 28, 2016, 48-71.

Kassianidou/Knapp 2005 - V. Kassianidou/A. B. Knapp: Archaeometallurgy in the Mediterranean: The Social Context of Mining, Technology and Trade. In: E. Blake/ B. Knapp (eds.): The Archaeology of Mediterranean Prehistory. London 2005, 215-251.

Kavtaradze 1981 - G. Kavtaradze: Saqartvelos eneolit-brinjaos khanis arqeologiuri kulturebis qronologia akhali monatsemebis shuqze (The Chronology of Georgian Aeneolithic-Bronze Age Archaeological Cultures in the Light of New Data). Tbilisi 1981.

Kleitsas 2019 - Chr. Kleitsas: The Hoard of Rodotopi in Ioannina (Epirus, NW Greece) and the Copper Single-Edged Shaft-Hole Axes of the Early Bronze Age in the Helladic Area. Archäologischer Anzeiger 1, 2019, 1-41.

Klochko/Klochko 2013 - V. I. Klochko/L. Klochko: Complex of Metal Goods Between the Vistula and Dnieper Rivers at the Turn of 4000-3000 to 3000 BC. Concept of the Carpathian - Volhynia 'Willow Leaf' Metallurgy Centre. Baltic-Pontic Studies 18, 2013, 36-68.

Korenevskij/Berezin/Gabuev 2018 - S. N. Korenevskij/Ya. B. Berezin/T. A. Gabuev: Unikal'noe pogrebenie epochi srednej bronzy na Kavminvodach. Kratkie soobshcheniya Instituta arkheologii 252, 2018, 67-86.

Koridze 1965 - D. Koridze: Kolkhuri kulturis istoriisatvis (Zur Geschichte der Kolchis-Kultur). Tbilisi 1965.

Korochkova et al. 2010 - O. N. Korochkova/S. V. Kuzminykh/Y. B. Serikov/V. I. Stefanov: Metals from the ritual site of Shaitanskoye Ozero II (Sverdlovsk Oblast, Russia). Trabajos de Prehistoria 67, 2010, 489-499.

Kubyshev/Chernyakov 1985 - A. I. Kubyshev/I. T. Chernyakov: K problematike sushchestvovaniya vesovoj sistemy u plemen bronzovogo veka stepej Vostochnoy
Evropy na materialakh liteyshchika katakombnoy kul'tury. Sovetskaya arkheologiya 1, 1985, 39-53.

Kuftin 1949 - B. A. Kuftin: Materialy k arkheologii Kolkhidy I. Tbilisi 1949.

Kuftin 1950 - B. A. Kuftin: Materialy $k$ arkheologii Kolkhidy II. Tbilisi 1950.

Kvirkvaia/Jibladze 2019 - R. Kvirkvaia/L. Jibladze: Litonis artefaqtebi sofel Zeda ilemidan (Metal Artifacts from Village Zeda Ilemi). Online Archaeology (Tbilisi) 15, 2019, 50-62.

Kvitsiani/Jibladze 2015 - Z. Kvitsiani/L. Jibladze: Uachlesi arqeologiuri agmochenbi svanetshi (The Latest Archaeological Discoveries in Svaneti). Tbilisi 2015.

Lordkipanidze 1991 - O. Lordkipanidze: Archäologie in Georgien. Von der Altsteinzeit zum Mittelalter. Quellen und Forschungen zur prähistorischen und provinzialrömischen Archäologie 5. Weinheim 1991.

Lordkipanidze 2001 - O. Lordkipanidze: "Gandzebi“ kolkhur brinjaos kulturashi, punktsiis depinitsiisa da kulturul-sotsiologiuri interpretatsiis tsda („Horte“ in der bronzezeitlichen Kolchis-Kultur. Der Versuch einer funktionalen Definition und kultursoziologischen Interpretation). In: O. Lordkipanidze (ed.): Dziebani sakartvelos metsnierebata akademiis arkeologiuri kvlevis tsentris zhurnali, damatebani VI. kavkasia neolit-brinjaos khanis arkeologiis sakitkhebi. edzg்vneba akad. o. japaridzis dabadebis 80 tslistavis gamo. Tbilisi 2001, 178-194.

Orjonikidze 2015 - A. Orjonikidze: Adreuli korǵanbi saqartveloshi (The Earlier Period Kurgans in Georgia). Tbilisi 2015.

Patay 1943 - P. Patay: Rézkori lelet Mezősasról (Kupferzeitliche Funde aus Mezősas). Dolgozatok a Magyar Királyi Tudományegyetem Régiségtudományi Intézetéből 19, 1943, 135-142.

Pfeiffer 2009 - K. Pfeiffer: The Technical Ceramic for Metallurgical Activities in Tall Hujayrat al-Ghuzlan and Comparable Sites in the Southern Levant. In: L. Khalil/ K. Schmidt (eds.): Prehistoric Aqaba 1. Rahden/Westf. 2009, 305-338.

Pkhakadze 1993 - G. Pkhakadze: Dasavlet amierkavkasia dzveli tselataagritkhvis III atastsleulshi (The western Transcaucasus in the III Mill. B. C.). Tbilisi 1993.

Pulszky 1884 - F. Pulszky: Die Kupferzeit in Ungarn. Budapest 1884

Ramishvili 1974 - A. Ramishvili: Kolchetis materialuri kulturis istoriidan (Aus der Geschichte der materiellen Kultur der Kolchis). Batumi 1974.

Reinhold 2005 - S. Reinhold: Vom Ende Europas? Zu den Depotfunden im Kaukasus. In: B. Horejs/R. Jung/ E. Kaiser/B. Teržan (Hrsg.): Interpretationsraum Bronzezeit. Bernhard Hänsel von seinen Schülern gewidmet. UPA 121. Bonn 2005, 345-373.

Rikzana/Seeher 1989 - I. Rikzana/J. Seeher: Maadi III. The Non-Lithic Small Finds and the Structural Remains of the Predynastic Settlement. Abhandlungen des Deutschen Archäologischen Instituts, Abteilung Kairo 80. Mainz 1989.

Sava 2015 - V. Sava: Neolithic and Eneolithic in the Lower Mureş Basin. Cluj-Napoca 2015.

Šljivar/Kuzmanović-Cvetković/Živković 2011 - D. Šljivar/ J. Kuzmanović-Cvetković/J. D. Živković: Belovode, Pločnik; on Copper Metallurgy in the Vinča Culture. Zbornik Narodnog muzeja u Beogradu 22/1, 2011, 27-45.

Stöllner/Gambashidze 2018 - T. Stöllner/I. Gambashidze: Das prähistorische Siedlungsplateau Dzedzwebi nahe Balitschi in Unterkartli. In: L. Giemsch/S. Hansen 
(Hrsg.): Gold und Wein. Georgiens älteste Schätze. Begleitband zur Sonderausstellung 6. Oktober 2018 - 10. Februar 2019 Archäologisches Museum Frankfurt. Mainz 2018, 150-157.

Tchabashvili/Bastert-Lamprichs/Giemsch 2018 - L. Tchabashvili/K. Bastert-Lamprichs/L. Giemsch: Objekte der Ausstellung. In: L. Giemsch/S. Hansen (Hrsg.): Gold und Wein. Georgiens älteste Schätze. Begleitband zur Sonderausstellung 6. Oktober 2018 - 10. Februar 2019 Archäologisches Museum Frankfurt. Mainz 2018, 257-353.

Truhelka 1909 - C. Truhelka: Kupferfund von Kozarac. Wissenschaftliche Mitteilungen aus Bosnien und der Herzegovina 11, 1909, 54, 55.

Voronov 1969 - Yu. N. Voronov: Arkheologicheskaya karta Abkhazii. Sukhum 1969.

Wang et al. 2019 - C.-C. Wang/S. Reinhold/A. Kalmykov/ A. Wissgott/G. Brandt/C. Jeong/O. Cheronet/
M. Ferry/E.Harney/D. Keating/S. Mallick/ N. Rohland/K. Stewardson/A. R. Kantorovich/V. E. Maslov/V. G. Petrenko/V. R. Erlikh/B. Ch. Atabiev/ R. G. Magomedov/P. L. Kohl/K. W. Alt/S. L. Pichler/ C. Gerling/H. Meller/B. Vardanyan/L. Yeganyan/ A. D. Rezepkin/D. Mariaschk/N. Berezina/J. Gretsky/ K. Fuchs/C. Knipper/S. Schiffels/E. Balanovska/ O. Balanovsky/I. Mathieson/T. Higham/Y. B. Berezin/ A. Buzhilova/V. Trifonov/R. Pinhasi/A. B. Belinskij/ D. Reich/S. Hansen/J. Krause/W. Haak: Ancient human genome-wide data from a 3000-year interval in the Caucasus corresponds with eco-geographic regions. Nature Communications 10, 2019, Article number: 590 .

Worsaae 1866 - J. J. A. Worsaae: Om nogle mosefund fra Broncealderen. Aarbøger for Nordisk Oldkyndighed og Historie 1866, 313-326.

Manuscript accepted 31. 7. 2020

Translated by Joni Apakidze and Svend Hansen

Súhrn preložila Anita Kozubová

Prof. Dr. Joni Apakidze

Eurasien-Abteilung des Deutschen Archäologischen Instituts

Im Dol 2-6

D - 14195 Berlin

joni.apakidze@dainst.de
Prof. Dr. Dr. h. c. Svend Hansen

Eurasien-Abteilung des Deutschen Archäologischen Instituts

Im Dol 2-6

D - 14195 Berlin

svend.hansen@dainst.de

\title{
Dva depoty sekier s otvorom $\mathrm{v}$ tyle $\mathrm{z}$ doby bronzovej zo západného Gruzínska Materiály ku kontaktom medzi strednou a východnou Európou
}

\author{
Joni Apakidze - Svend Hansen
}

\begin{abstract}
SÚHRN
Predložená práca je venovaná analýze dvoch depotov sekier s otvorom v tyle z Gruzínska. Neúplne zachovaná sekera z depotu zo Saqasrie patrí k typu, ktorý je bežný v Zakaukazsku a vyznačuje sa úzkou dlhou tulajkou und mierne rozšíreným ostrím. Analógie k tomuto typu sekier pochádzajú v západnom Gruzínsku najmä z hrobov zo Sachkhere. Kým sekery s mierne rozšíreným ostrím patria k typickým zakaukazským typom zbraní, sú sekery s odsadeným ostrím rozšírené na väčšom území ako typ Sachkhere a na Západe sú pomenované podla jedného depotu v Bosne a Hercegovine ako typ Kozarac. Sekery typu Kozarac boli okrem juhovýchodnej Európy rozšírené aj v severopričiernomorskej oblasti a sú datované rovnako ako sekery typu Sachkhere do prvej polovice 3. tisícročia pred n. 1 .

$\mathrm{K}$ oválnemu, plano-konvexnému ingotu z depotu zo Zeda Ilemi nenachádzame v Zakaukazsku žiadne porov-

natel'né ingoty. Naopak, kadluby na odlievanie ingotov podobného tvaru ako ingot zo Zeda Ilemi pochádzajú z hrobu katakombovej kultúry z Malej Ternivky na Ukrajine (Záporožská oblast') a z hrobu 10 v mohyle z Lebedi, ktorý je možné datovat na začiatok 3. tisícročia pred n. 1 .

Depoty zo Saqasrie a Zeda Ilemi, ktoré obsahovali sekery s otvorom v tyle typu Kozarac a Sachkhere, je možné chronologicky zaradit do prvej polovice 3. tisícročia pred n. l., čo potvrdzuje aj rádiouhlíkové datovanie hrobu 4 v mohyle 3 na pohrebisku Lysogorskaja-6 na severnom Kaukaze (Stavropolský kraj). Na základe tohto zistenia je zrejmé, že počiatky deponovania kovových predmetov v západnom Gruzínsku sú staršie ako sa doteraz predpokladalo. Nielen sekery, ale aj spôsob ako boli deponované, sú dokladom kontaktov medzi karpatským a kaukazským regiónom.
\end{abstract}

